\title{
Lateral
}

Journal of the Cultural Studies Association

\section{Review of Digitize and Punish: Racial Criminalization in the Digital Age by Brian Jefferson (University of Minnesota Press)}

\author{
by Anastasia Kārklina I Book Reviews, Issue 10.1 (Spring 2021)
}

\begin{abstract}
In Digitize and Punish, Brian Jefferson argues that the US policing and incarceration infrastructure is increasingly marked by new forms of racialized digital criminalization. Examining the incorporation of digital technologies into the criminal justice apparatus, Jefferson shows the central role that digital technology and data science has had in reinforcing racial surveillance practices since the War on Drugs and Crime began more than four decades ago. Jefferson's timely new book traces the merging of carcerality and technology in Chicago and New York City, unveiling forms of digital racial management that have remained largely obscured from the public.
\end{abstract}

KEYWORDS abolitionism, carcerality, criminalization, police, surveillance, technology

Digitize and Punish: Racial Criminalization in the Digital Age. By Brian Jefferson. Minneapolis, MN: University of Minnesota Press, 2020. 232 pp. (paperback) ISBN: 9781517909239. US List: $\$ 24.95$.

Mass protests against police violence this summer have prominently placed the issue of policing at the forefront of the national discourse, reinvigorating abolitionists' decadeslong demands to end carceral logics that organize social life in the United States. In Digitize and Punish, Brian Jefferson reveals an alarming side of policing and state surveillance that remains largely obscured from the public. While public outrage has been evoked by highly visible instance of police violence, Jefferson wants to consider more insidious forms of racial governance. The tech industry is responsible for new forms of social control that have been made possible by the consolidation of carceral logics and technology. Digital computing has been silently incorporated into the policing apparatus, pushed by leaders in the IT industry, tech research, and government. In a digital carceral state, Jefferson argues, the database-and not the prison cell-is the new frontier of the criminal justice apparatus.

Brian Jefferson's Digitize and Punish lays out its argument with clarity and purposeful precision, and is remarkably timely in light of national conversations about policing. Jefferson situates his research within the abolitionist struggle against police and prisons, and activists' efforts to confront and resist the carceral state. The proliferation of prisons, jails, and detention centers, argues Jefferson, is not the only impetus for the crisis of mass incarceration in the United States. New criminal justice technologies that were marketed to the criminal justice system by private tech firms and corporations have extended and formalized carceral surveillance of populations that are deemed expendable beyond the 
walls of these facilities. At the heart of the book lies an urgent concern with the way in which new computational technologies have been integrated into the criminal justice apparatus to surveil, manage, and police criminalized communities.

But Jefferson is not simply advocating for eliminating digitized forms of policing and criminalization. His expository analysis of how urban criminality was understood and conceptualized in the late nineteenth and early twentieth centuries demonstrates how biometric data and digital technologies became "commonsense solutions to social problems" (184). In this sense, it is the cultural ideology of policing, Jefferson shows, that makes the practices of digitized surveillance possible in the first place. In short, a crucial part of Jefferson's critique here is aimed not only at the use of technology in the criminal justice system as such but at the socio-political conditions that made digitized surveillance not only possible but desirable.

In the first chapter, Jefferson clearly articulates how, with the invention of the electromechanical tabulator, early data on prisoner offenses established a direct link between racial identifiers and different types of criminal offenses. At the turn of the twentieth century, the production of "criminological knowledge" (24) was tainted by "biological and cultural explanations" (27) of criminality that understood deviancy to be the result of racial difference. But even as criminologists moved away from biological racism and its pseudoscientific belief in racial inferiority and instead focused on the role of physical environments, this new attention to what Jefferson calls "social ecology," nevertheless, produced criminal data that perpetuated the assumption that criminality was inherent to "negatively racialized, criminalized urban areas" (31). This patently solidified associations between blackness and criminality, framed crime as innate to communities that were economically deprived and historically disadvantaged, and eventually laid the necessary ideological groundwork for the merging of policing and digital computing in the 1960 s $(27,24)$. Digitized criminalization, however, did not occur in isolation. It was made possible precisely because production of new digital technologies and their integration into the policing apparatus was a lucrative venture for IT companies that sprung out of emerging tech hubs across the country. Jefferson introduces readers to the nuances of how private technology firms, such as Lockheed Martin and IBM, intentionally marketed new computing technologies to investigative units and police departments, their efforts aided by computer scientists, criminologists, and state officials.

To this end, one of Jefferson's main arguments in Digitize and Punish is that data science is not neutral. It is inherently political; it is production of knowledge as well as technology. Throughout the book, Jefferson pays particularly attention to how developers of new carceral technologies approach the policing apparatus as, first and foremost, a profitable window of opportunity to "digitally carceralize" historically oppressed communities (61). While "southern segregationists normalized racialized policing through biological racism, explicit laws, and overt racial demagoguery," Jefferson argues that "northern powers normalized it through mathematical formulas" (63).

In the second chapter, Jefferson shows how the adaptation of digital technology coincides with mass incarceration: automation became a more efficient way to process rising numbers of inmates, while new video technologies, tracking devices, and "riskassessment algorithms" enhanced carceral surveillance of prison populations (75). What readers will appreciate about the third and the fourth chapters of Digitize and Punish is the focus provided by Jefferson's in-depth interrogation of the use of computer technology in police departments in Chicago and New York City, such as computer-aided sweeps, spatial 
analysis software, and the role of wireless networks. These chapters both reveal strategies of policing that are obscured from the public eye and contextualize practices that we take for granted: for example, the emergence of wireless network technology made criminal databases widely available to the public over the Internet. Anyone with access to the web -including non-profits, banks, state agencies, and private companies-could now freely access criminal data for any reason, including reviewing or even selling background checks on select individuals. In the fifth and last chapter, Jefferson demonstrates how the steady digitalization of policing mechanisms profoundly alters urban geography, such that new technologies, including smart cameras, environmental sensors, and GPS monitors, form a new kind of hyper-carceral ecosystem that will likely result in emergent forms of racial management that have not been seen before.

Jefferson's compelling and visionary book pays close attention both to contextual breadth and qualitative depth. Digitize and Punish attends to the larger socio-historic context and is, at the same time, laser-focused in its evaluation of specific technologies. Over the course of the book, the author supplements case studies with narratives of historical conditions that provide superb analytical value and points of connection for readers in adjacent disciplines.

Digitize and Punish will be of great interest to scholars not only in the fields of geography, information science, and technology studies, but also those interested in the history of policing in the United States, urban sociology, and race and ethnicity studies more broadly. Finally, this book would undoubtedly be a valuable resource not only for academic audiences but also for technology and policy professionals who are are invested in understanding technological innovation and its social implications through the lens of racial justice.

\section{Author Information}

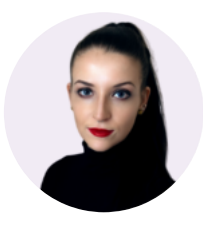

\section{Anastasia Kārkliṇa}

Anastasia Kārklina is a cultural analyst and a PhD candidate in the Program in Literature at Duke University, where she specializes in Black studies and feminist theory. Her research interests include Black radical thought and imagination and the politics of race and gender in contemporary US culture. Anastasia holds a BA in African and African American Studies and Political Science, also from Duke University.

View all of Anastasia Kārklina's articles.

\section{Article details}

Anastasia Kārklina, "Review of Digitize and Punish: Racial Criminalization in the Digital Age by Brian Jefferson (University of Minnesota Press)," Lateral 10.1 (2021).

https://doi.org/10.25158/L10.1.26 
This content is licensed under a Creative Commons Attribution-NonCommercial 4.0 International License. Copyright is retained by authors.

Lateral is the peer-reviewed, open access journal of the Cultural Studies Association.

ISSN 2469-4053 